\title{
A Case of Merkel Cell Carcinoma of the External Auditory Canal Skin with Annulus and Tympanic Membrane
}

\author{
Ara Cho ${ }^{1}$ Mi Jang ${ }^{2}$, In Seok Moon ${ }^{1}$, and Seung Ho Shin ${ }^{1}(\mathbb{C}$ \\ ${ }^{1}$ Departments of Otorhinolaryngology, ${ }^{2}$ Pathology, Yonsei University College of Medicine, Seoul, Korea
}

외이도에 발생한 Merkel 세포암 1예

조아라 ${ }^{1}$ 장 미 $^{2} \cdot$ 문인석 ${ }^{1} \cdot$ 신승호 $^{1}$

연세대학교 의과대학 이비인후과학교실, ${ }^{1}$ 병리학교실 ${ }^{2}$

\author{
Received August 7,2020 \\ Revised November 19, 2020 \\ Accepted November 19, 2020 \\ Address for correspondence \\ Seung Ho Shin, MD \\ Department of Otorhinolaryngology, \\ Yonsei University \\ College of Medicine, \\ 50-1 Yonsei-ro, Seodaemun-gu, \\ Seoul 03722, Korea \\ Tel $+82-2-2228-3601$ \\ Fax $+82-2-2227-7875$ \\ E-mail SHINS@yuhs.ac
}

\begin{abstract}
Merkel cell carcinoma is an extremely rare neuroendocrine neoplasm of the external auditory canal (EAC) skin, which requires wide excision and adjuvant radiation due to a high recurrence rate. In this report, we describe a case of Merkel cell carcinoma arising from the EAC which was successfully treated with endoscopic excision. A 32-years-old female patient with a history of papillary thyroid cancer was diagnosed with an EAC tumor incidentally. There was a erythematous papular lesion on the posterior EAC without any evidence of locoregional metastasis. The patient underwent endoscopic tumor resection under general anesthesia, and the final pathologic report confirmed the diagnosis of Merkel cell carcinoma. There was no clinical or radiographic evidence of recurrence or metastasis of Merkel cell tumor for 41 months after surgical resection alone. Korean J Otorhinolaryngol-Head Neck Surg 2021;64(7):500-4
\end{abstract}

Key Words External auditory canal $\cdot$ Merkel cell carcinoma $\cdot$ Prognosis.

\section{서 론}

Merkel 세포는 진피 내에 존재하는 신경내분비세포(neuroendocrine cell) 중 하나이다. Merkel 세포암은 1972년 Toker ${ }^{1)}$ 에 의해 처음 소개되었으며 백만 명당 4명 정도의 발생률을 가 진 드문 악성종양으로 주로 60대 이상의 고령에서 발생한다. 종양은 전체의 $50 \%$ 가 두경부에서 발생하는데, 외이도에 발 생한 경우는 전 세계적으로 매우 드물게 보고되고 있다. ${ }^{2,3)}$

표준 치료는 아직까지 정립되지 않았으나 영역림프절로의 전이나 원격 전이 및 재발이 빈번하게 발생하여 국소절제만 으로는 불충분하다는 의견이 우월하다. Kokoska 등는 35 명 의 환자를 대상으로 31 개월간 추적 관찰을 시행하였을 때 국 소절제와 함께 예방적 경부절제술, 수술 후 방사선치료를 함

This is an Open Access article distributed under the terms of the Creative Common Attribution Non-Commercial License (https://creativecommons.org/licenses/by-nc/4.0) which permits unrestricted non-commercial use, distribution, and reproduction in any medium, provided the original work is properly cited.
께 시행하여 국소 및 원격 재발을 낮추고 생존율을 높인다고 보고하였다. 다른 연구에서도 181 명의 환자를 대상으로 국소 절제술을 시행한 환자에서 국소재발이 흔하다는 결과를 보 였다. 이처럼 대부분의 환자에서 수술 후 방사선치료를 병행 하며, 광범위한 절제와 방사선치료에도 불구하고 1년 생존율 은 85\%, 5년 생존율은 62\%, 10년 생존율은 47\%로 보고된 바 있다. ${ }^{5)}$

저자들은 외이도에 국한된 Merkel 세포암종에서 국소적인 절제수술 단독 시행 후 재발 없이 경과 관찰 중인 증례에 대 하여 문헌 고찰과 함께 보고하는 바이다.

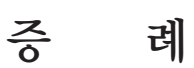

32세 여자 환자가 내원 2개월 전 우연히 발견된 좌측 외이 도의 종괴를 주소로 내원하였다. 과거력으로 내원 44개월 전 갑상선 유두상암 진단하 갑상선 전절제 수술을 받았다. 귀 내 
시경 검사에서 좌측 외이도 후방에 $3 \times 2 \mathrm{~mm}$ 의 크기의 붉고 구진상의 종물이 있었으며(Fig. 1A), 주위 조직이나 경부에 전이를 의심할만한 특별한 소견은 관찰되지 않았다. 측두골 전산화단층촬영에서 좌측 외이도에 폴립양상의 연조직 종물 확인되었으며, 골침범 소견은 관찰되지 않았다(Fig. $1 \mathrm{~B}$ and C). 순음 및 어음청각검사, 임피던스 청력검사 결과는 정상이 었다.

상기 결과를 토대로 경계가 분명하고 침습적이지 않은 양 성 종양을 의심하였고, 조직검사와 종양 제거를 함께 시행하 기 위해 내시경을 이용한 절제생검을 시행하였다(Fig. 2A). 수술 시 종물은 단단하였고 고막을 포함한 주위에 고정된 상
태로 고막의 일부를 포함하여 절제생검을 시행하였다. 절제한 조직은 $3 \times 2 \mathrm{~mm}$ 크기의 경계가 명확한 종양이었으며 내시경 소견에서 주변 조직으로의 침윤이나 이소골 또는 안면신경으 로의 침범은 보이지 않았다.

병리조직학적 검사 결과 외이도에서 기원한 종양이 고실륜 을 침범하였으며 세포질이 적은 푸른빛의 작고 둥근 세포들 이 진피에 판상(sheet) 혹은 섬유주(trabecular) 형태의 구조 를 이루고 있는 양상을 보였다. 이러한 종양세포는 cytokeratin 20(CK20)에 대한 면역조직화학염색에서 종양세포 핵 주 변으로 점상의 양성반응을 보이며, syneptophysin 염색 역시 양성 소견을 보여 Merkel 세포암으로 확진되었다(Fig. 3).
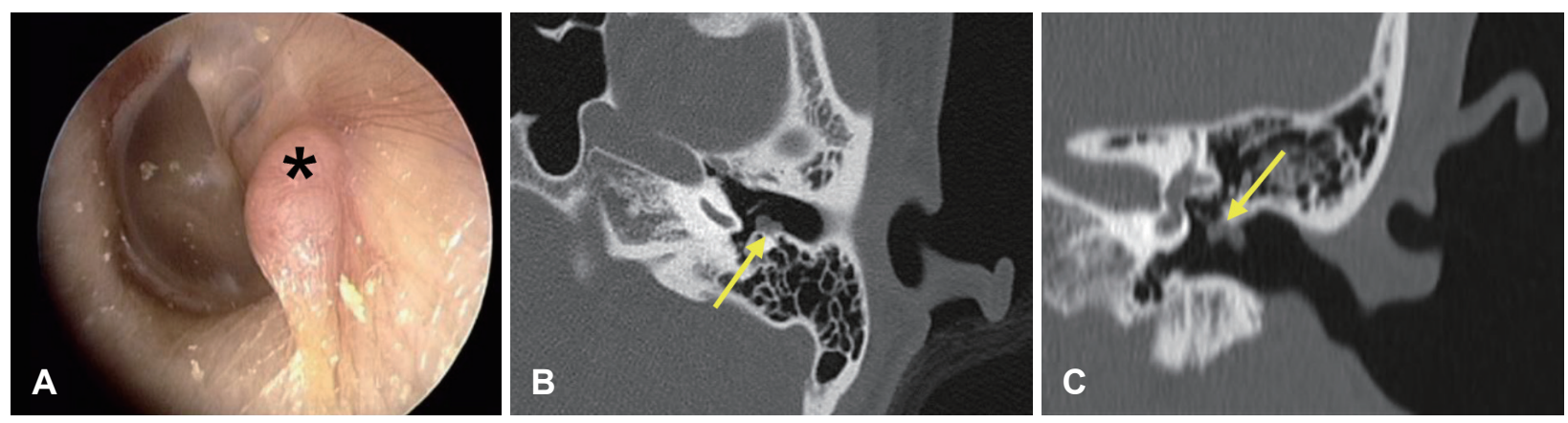

Fig. 1. Preoperative evaluations. Preoperative otoendoscopic finding of the left ear shows $3 \times 2 \mathrm{~mm}$ reddish nodular lesion at left posterior EAC (asterisk) (A). Preoperative temporal bone CT imaging shows a small polypoid soft tissue mass arising from the superior walls of left medial EAC (arrows) in axial view (B) and coronal view (C). EAC: external auditory canal.
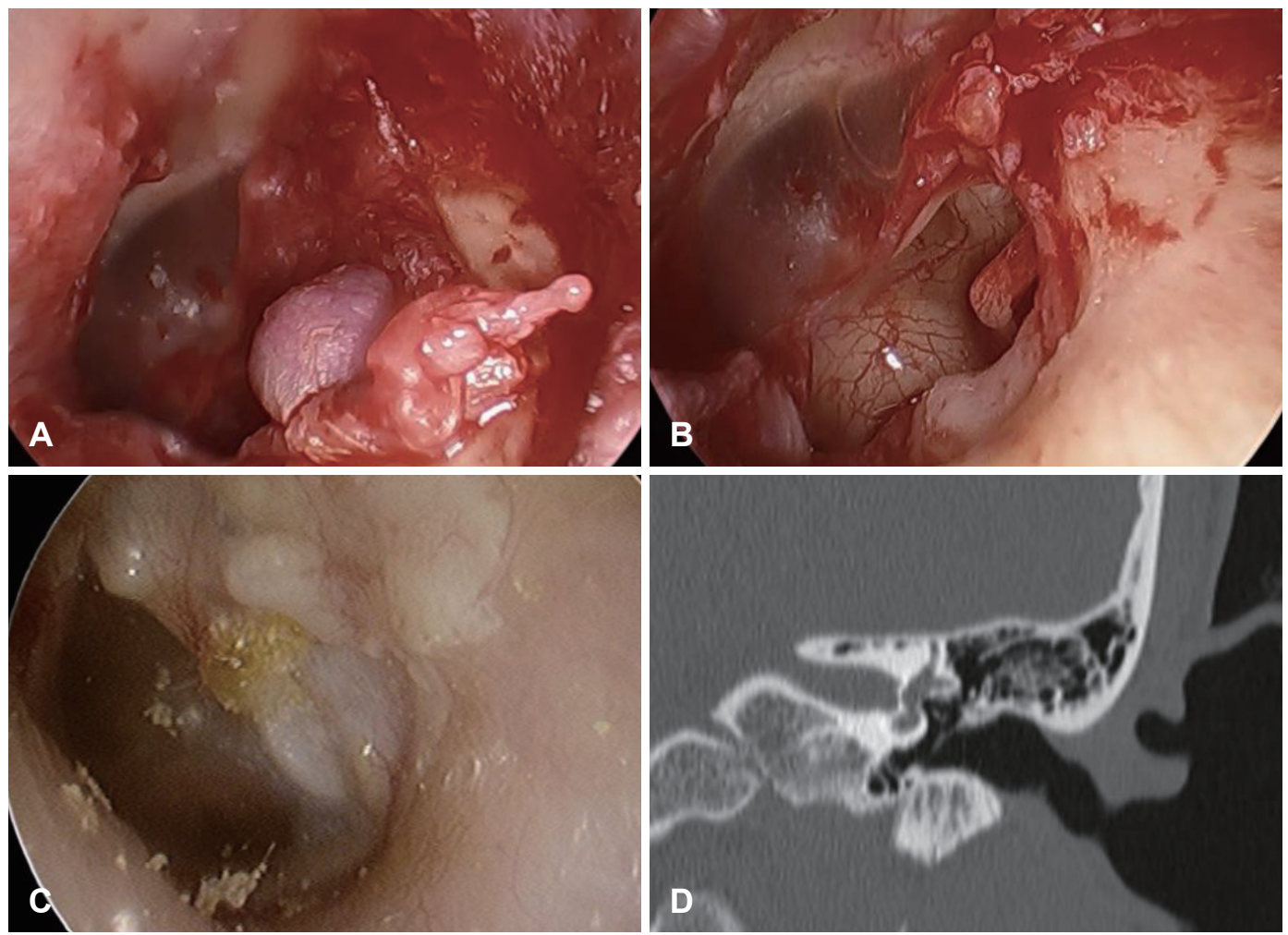

Fig. 2. Intraoperative and postoperative endoscopic findings. Intraoperative endoscopic view before and after extirpation of tumor from external auditory canal (A, B). Endoscopic view of postoperative surgical site at 41 months follow-up (C). Postoperative CT scan (D). 

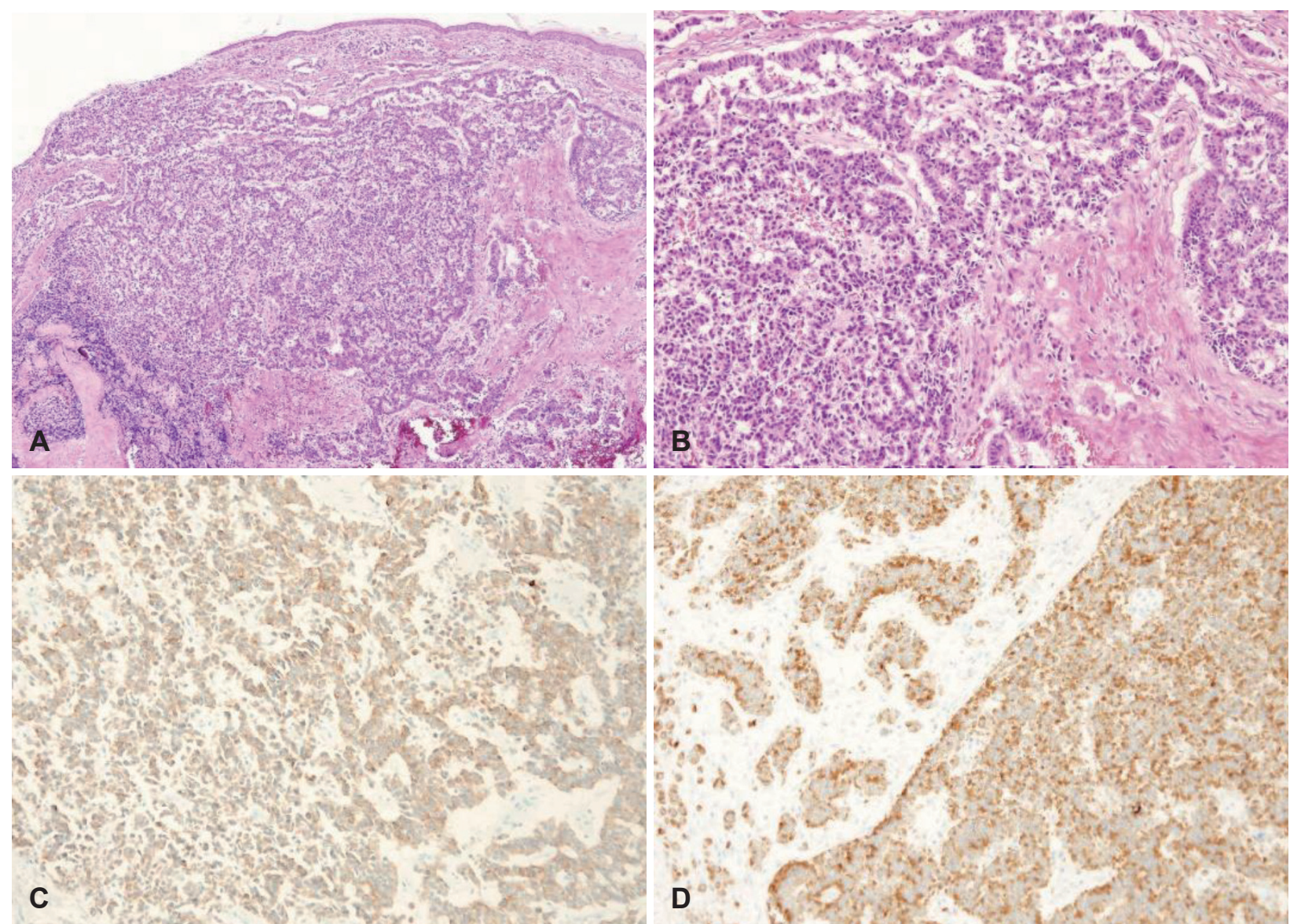

Fig. 3. Histologic features and immunoprofiles of the Merkel cell carcinoma. Tumor shows nodular expansile and partly infiltrative growth pattern $(H \& E, \times 40)(A)$. Trabecular and cord like structures are characteristic features $(H \& E \times 200)(B)$. Tumor cells show positive expression for synaptophysin $(\times 100)(C)$ and CK20 $(\times 100)(D)$ immunohistochemical stain. H\&E: hematoxylin and eosin.

수술 후 시행한 자기공명영상에서 잔존하는 종물 및 주위 임파선으로의 전이 소견이나 양전자방출단층촬영에서 타 장 기로의 전이 소견은 관찰되지 않아 the American Joint Committee on Cancer(AJCC) 병기체계상 1기에 해당하였다. 종양이 매우 작고 주위 조직과의 경계가 분명하게 제거되어 추가적인 방사선치료는 하지 않았으며 41개월간 신체검진 및 자기공명영상에서 재발소견 없이 추적 관찰 중이다(Fig. 2 C).

\section{고 찰}

Merkel 세포는 진피 내에서 특수감각기관의 역할을 하는 세포로서, 세포질 내에 melanin 과립과 신경전달 과립을 가 지고 있어 그 기원을 신경릉의 외배엽줄기세포라고 추정하고 있다. Merkel 세포암은 매우 드문 피부의 신경내분비 암종으 로 알려져 있으며, 1972년 Toker ${ }^{1)}$ 에 의해 처음으로 지주 암 종(trabecular carcinoma)이라 명명되어 보고되었다.

보고에 따라 다소 차이가 있으나 전체의 약 $50 \%$ 이상이 두 경부에서 나타나며 협부, 비부, 안구 주위에 호발한다. 60 70
대의 고령에 발생하고 평균 연령은 69세로 보고되고 있으며, 주로 백인종에 호발하며 성별에 따른 발생의 차이는 크지 않 으나 연구에 따라 차이를 보인다. ${ }^{6)}$ 외이도에서 기원한 Merkel cell carcinoma는 전세계적으로 매우 드물게 보고되고 있으 며, 평균 69세의 고령의 환자에게서 발병하는데 본 증례 환 자는 32세로 흔하지 않은 흥미로운 증례이다.

최근 발병률은 증가하는 추세로 1986 2001년까지 연령을 보정한 발병률은 8\% 증가하였으며,' 네덜란드에서도 1993 1997년 사이 백만 명당 1.7명에서 2003 2007년 사이 3.5명으 로 발병률이 증가하였다. ${ }^{8}$ 전이와 재발도 흔하게 나타나 25\% $30 \%$ 의 환자에서 재발이 나타나며 국소전이는 $52 \%$ 59\%, 원 거리 전이는 34\% 36\%로 보고되었다. 임상적 병기에 대해서는 최근까지도 정립되지 않아 지난 20년간 5 가지의 체계가 제안 되었으며 AJCC에서 2018년 제안한 병기체계와 그에 따른 5년 생존율은 다음과 같다(Table 1).

임상적으로 수주에서 수개월간 빠르게 증가하는 붉은 보랏 빛의 단단한 결정성 종괴로 매끄러우며 광택이 있는 표면을 보여9) 본 증례의 진찰 소견과 일치하였다. 본 증례에서는 우 
Table 1. Merkel cell carcinoma staging system and 5-year survival rate proposed by AJCC ${ }^{15)}$

\begin{tabular}{ccccc}
\hline Stage & Primary tumor & Nodes & Metastasis & 5 -year survival (\%) \\
\hline 0 & In situ & Negative & None & $55-78$ \\
I & $\leq 2 \mathrm{~cm}$ & Negative & None & $55-78$ \\
IIA & $>2 \mathrm{~cm}$ & Negative & None & $55-78$ \\
IIB & Invade muscle, bone or cartilage & Negative & None & $27-52$ \\
IIIA & Any & Micrometastasis & None & $27-52$ \\
IIIB & Any & Macrometastasis & None & $27-52$ \\
IV & Any & Any & Distant metastasis & $14-19$ \\
\hline
\end{tabular}

연히 발견된 외이도 종괴를 주소로 내원하여 환자가 호소하 는 특이 증상이 없었으나 경우에 따라 무통성의 종괴와 함께 전음성 난청을 보일 수 있으며 소양감, 간헐적 이통 및 수양성 분비물을 호소할 수 있다. ${ }^{3)}$

Merkel 세포암의 표준 치료는 원격전이가 없는 환자에서는 종양을 완전절제하는 것이다. 절제연으로부터 2 3 cm까지 포함하여 절제하는 것이 추천되며, 광범위한 절제술을 시행 한 경우에 무병생존율(disease free survival)을 개선시킨다고 보고된 바 있다. ${ }^{4)}$ 예방적인 경부 림프절 곽청술은 술자에 따 라 다르게 적용된다. 현재까지는 림프절 전이가 없는 환자는 약 15\% 20\%에 불과하므로 전신 컨디션이 양호하다면 선택적 경부 림프절 곽청술을 치료에 포함해야 한다는 의견이 대체 적이나, ${ }^{10)}$ 다른 연구에서는 $1 \mathrm{~cm}$ 미만의 작은 병변에서는 국 소 림프 전이의 가능성이 낮아 선택적 경부 림프절 곽청술이 필요 하지 않다고 제안하기도 하였다. ${ }^{11)}$ 국소 방사선치료가 수 술 이후의 재발, 전이를 낮춘다는 것이 많은 연구를 통하여 보고되었으며, ${ }^{12)}$ 일부에서는 방사선 치료를 단독으로 시행하 는 것을 주장하기도 하였으나 기존의 광범위절제술과 방사선 치료를 함께 시행한 대조군에 비하여 유의한 이득을 보이지 않았다. ${ }^{13)}$ 항암치료는 재발이나 원거리 전이가 있는 경우 완 화목적으로 사용되는 것이 일반적이며 Merkel 세포암에 특 이적인 표준 항암치료는 정립되지 않아 세포학적 유사성을 고려하여 소세포폐암과 유사하게 치료한다. Merkel 세포암 에 특이적인 표적치료가 연구중이며 최근 Merkel cell polyomavirus $(\mathrm{MCV})$ 가 병태생리에 관여한다는 연구결과를 기반 으로 이를 이용한 면역 조절 치료가 제시되고 있다. Merkel cell carcinoma와 $\mathrm{MCV}$ 의 관계는 아직 충분히 밝혀지지 않 았으나 $\mathrm{MCV}$ 의 T항원이 short hairpin RNA(shRNA)를 매 개로 하여 세포성장과 사멸을 조절하는 과정에서 Merkel cell carcinoma의 발생에 기여하는 것으로 생각되며 항바이러스 효과가 있는 interferon- $\alpha, \beta$ 등이 Merkel cell carcinoma의 치료에 제안되기도 하였다. ${ }^{14)}$

본 증례에서는 수술 전 진찰소견 및 영상검사에서 경계가 명확하며 침습적이지 않은 양성 종양이 의심되어 조직검사와
완전절제를 함께 시행하는 수술적 치료를 시행하였다. 병리조 직학 검사에서 Merkel cell carcinoma로 최종 진단되었으나 종양의 크기가 $1 \mathrm{~cm}$ 미만으로 매우 작고 수술 전후의 진찰 소견과 영상검사에서 전이 소견을 보이지 않았으며 경계가 명확하게 제거되어 추가 경부 절제술 및 방사선치료는 시행 하지 않았으며 정기적인 신체진찰 및 자기공명영상검사를 통 하여 재발 여부를 추적 관찰하고 있다. 이처럼 임상적 병기가 낮은 Merkel cell carcinoma는 국소절제수술 단독 시행만으 로도 좋은 예후를 보일 수 있다는 점을 시사하여 문헌 고찰 과 함께 보고하는 바이다.

\section{Acknowledgments}

None.

\section{Author Contribution}

Conceptualization: Seung Ho Shin. Supervision: In Seok Moon. Writing — original draft: Ara Cho, Mi Jang. Writing-review \& editing: Ara Cho, In Seok Moon, Seung Ho Shin.

\section{ORCIDs}

Seung Ho Shin

In Seok Moon

https://orcid.org/0000-0001-9352-8426

https://orcid.org/0000-0002-3951-5074

\section{REFERENCES}

1) Toker C. Trabecular carcinoma of the skin. Arch Dermatol 1972; 105(1):107-10

2) Xiu Q, Wang XJ, Zhu DD, Meng CD. Diagnosis and comprehensive therapy for cutaneous neuroendocrine carcinoma of the external auditory canal: A case report and literature review. Braz J Otorhinolaryngol 2018;84(6):799-801.

3) Petković M, Krstulja M, Radic J, Zamolo G, Muhvić D, Lovasic I, et al. Merkel cell carcinoma arising in the ear canal. Int J Surg Pathol 2008;16(3):337-40.

4) Kokoska ER, Kokoska MS, Collins BT, Stapleton DR, Wade TP. Early aggressive treatment for Merkel cell carcinoma improves outcome. Am J Surg 1997;174(6):688-93.

5) Pergolizzi J Jr, Sardi A, Pelczar M, Conaway GL. Merkel cell carcinoma: An aggressive malignancy. Am Surg 1997;63(5):450-4.

6) Pagella F, Semino L, Corno S, Colombo A, Benazzo M. Merkel cell carcinoma of the auricle. Am J Otolaryngol 2005;26(5):324-6.

7) Agelli M, Clegg LX, Becker JC, Rollison DE. The etiology and epidemiology of merkel cell carcinoma. Curr Probl Cancer 2010; 34(1):14-37. 
8) Reichgelt BA, Visser O. Epidemiology and survival of Merkel cell carcinoma in the Netherlands. A population-based study of 808 cases in 1993-2007. Eur J Cancer 2011;47(4):579-85.

9) Heath M, Jaimes N, Lemos B, Mostaghimi A, Wang LC, Peñas PF, et al. Clinical characteristics of Merkel cell carcinoma at diagnosis in 195 patients: The AEIOU features. J Am Acad Dermatol 2008;58(3):375-81.

10) Schwartz JL, Griffith KA, Lowe L, Wong SL, McLean SA, Fullen $\mathrm{DR}$, et al. Features predicting sentinel lymph node positivity in Merkel cell carcinoma. J Clin Oncol 2011;29(8):1036-41.

11) Stokes JB, Graw KS, Dengel LT, Swenson BR, Bauer TW, Slingluff $\mathrm{CL} J \mathrm{~J}$, et al. Patients with Merkel cell carcinoma tumors $<$ or $=1.0$ $\mathrm{cm}$ in diameter are unlikely to harbor regional lymph node metastasis. J Clin Oncol 2009;27(23):3772-7.

12) Ghadjar P, Kaanders JH, Poortmans P, Zaucha R, Krengli M,
Lagrange JL, et al. The essential role of radiotherapy in the treatment of Merkel cell carcinoma: A study from the Rare Cancer Network. Int J Radiat Oncol Biol Phys 2011;81(4):e583-91.

13) Pape E, Rezvoy N, Penel N, Salleron J, Martinot V, Guerreschi P, et al. Radiotherapy alone for Merkel cell carcinoma: A comparative and retrospective study of 25 patients. J Am Acad Dermatol 2011; 65(5):983-90.

14) Touzé A, Le Bidre E, Laude H, Fleury MJJ, Cazal R, Arnold F, et al. High levels of antibodies against merkel cell polyomavirus identify a subset of patients with merkel cell carcinoma with better clinical outcome. J Clin Oncol 2011;29(12):1612-9.

15) Harms KL, Healy MA, Nghiem P, Sober AJ, Johnson TM, Bichakjian CK, et al. Analysis of prognostic factors from 9387 Merkel cell carcinoma cases forms the basis for the new 8th edition AJCC staging system. Ann Surg Oncol 2016;23(11):3564-71. 